Marine Natural Products, IX

\title{
A New Halogenated Sesquiterpene Pinnatifidone from the Red Alga Laurencia pinnatifida
}

\author{
Shaheen Bano*, Mohammad Shaiq Ali, and Viqar Uddin Ahmad
}

H. E. J. Research Institute of Chemistry, University of Karachi, Karachi-32, Pakistan

Z. Naturforsch. 43b, 1347-1350 (1988); received November 19, 1987

Pinnatifidone, Halogenated Sesquiterpene, Red Alga, Laurencia pinnatifida (Lamour)

From the ethyl acetate fraction of methanolic extract of red alga, L. pinnatifida, a new halogenated sesquiterpene named as pinnatifidone [1] has been isolated and the structure of this compound has been elucidated with the help of intensive spectroscopic studies.

\section{Introduction}

The red algae of the genus Laurencia have been investigated extensively for their chemical constituents due to the interesting metabolites present in them. During an antimicrobial screening study of Arabian marine algae [1] significant activity was displayed against Bacillus subtilis, Bacillus megaterium, and Streptococcus viridans by methanolic extract of Laurencia pinnatifida. We were therefore motivated to initiate an investigation of its chemical constituents. Previously we have reported a new halogenated sesquiterpene [2] from the chloroform extract and now we wish to report another new halogenated sesquiterpene, pinnatifidone [1] from the same source which is a new addition to the compounds having ether linkage between $\mathrm{C}-1$ and $\mathrm{C}-10$ as in the case of pacifinol [3].

The structure of compound $\mathbf{1}$ was elucidated on the basis of spectral data including extensive spin decoupling experiments and 2D-homo- and heteronuclear correlated NMR spectroscopy as well as n.O.e. difference measurements. The absolute configuration was decided with the aid of $\mathrm{CD}$ spectrum.

\section{Results and Discussion}

Unlike the crude extract [1] the pure compound 1 was found to be inactive against three gram-positive bacteria.

Pinnatifidone has the molecular formula $\mathrm{C}_{15} \mathrm{H}_{22} \mathrm{O}_{2} \mathrm{BrCl}$ on the basis of FD mass spectrum ( $\mathrm{M}^{+}$ at $\mathrm{m} / z$ 352, 350, 348). Its IR spectrum exhibited ab-

\footnotetext{
* Reprint requests to Dr. S. Bano.

Verlag der Zeitschrift für Naturforschung, D-7400 Tübingen 0932-0776/88/1000-1347/\$ 01.00/0
}

sorption band at $1700 \mathrm{~cm}^{-1}$ for carbonyl group. There was no absorption due to a hydroxyl group. Therefore, one oxygen in the molecule is probably present in the form of ether.

The ${ }^{13} \mathrm{C}$ NMR spectrum accounted for fifteen carbon atoms. One peak for ketonic carbon appeared at $212.46 \mathrm{ppm}$, two tertiary carbons bearing oxygen functionality in the form of ether exhibited peaks at $84.72,79.50 \mathrm{ppm}$ while those of a tertiary and a quaternary carbon bearing halogens appeared at 60.40 and $70.95 \mathrm{ppm}$ respectively.

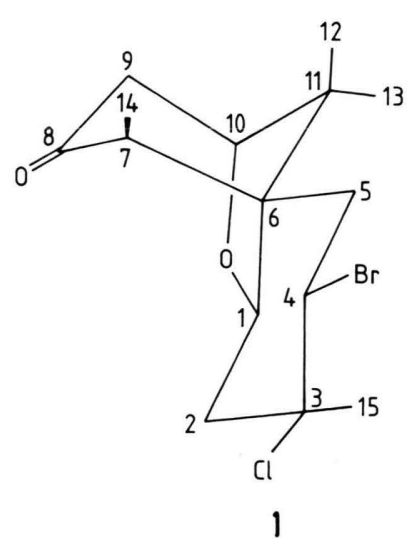

In the ${ }^{1} \mathrm{H}$ NMR spectrum a singlet at $\delta 1.80$ is due to a methyl group attached to a carbon bearing a halogen atom. Two more methyl singlets appeared at $\delta 1.04$ and 1.23 while the fourth methyl signal appeared as a doublet at $\delta 1.34$. The downfield shift of this methyl could be due to the deshielding effect of the ketonic function next to this methyl group. The spectrum also showed an equatorial methine proton signal at $\delta 4.01(\mathrm{t}, J=3.4 \mathrm{~Hz})$, two axial methine protons at $\delta 4.14(\mathrm{dd}, J=12.8,6.0 \mathrm{~Hz}), 4.38(\mathrm{dd}$, $J=13.8,7: 0 \mathrm{~Hz})$. 
The coupling between various protons and the carbon proton correlation were established by homoand heteronuclear 2D NMR spectroscopy (see Fig. 1 cosy-45 and Fig. 2 heterocosy).

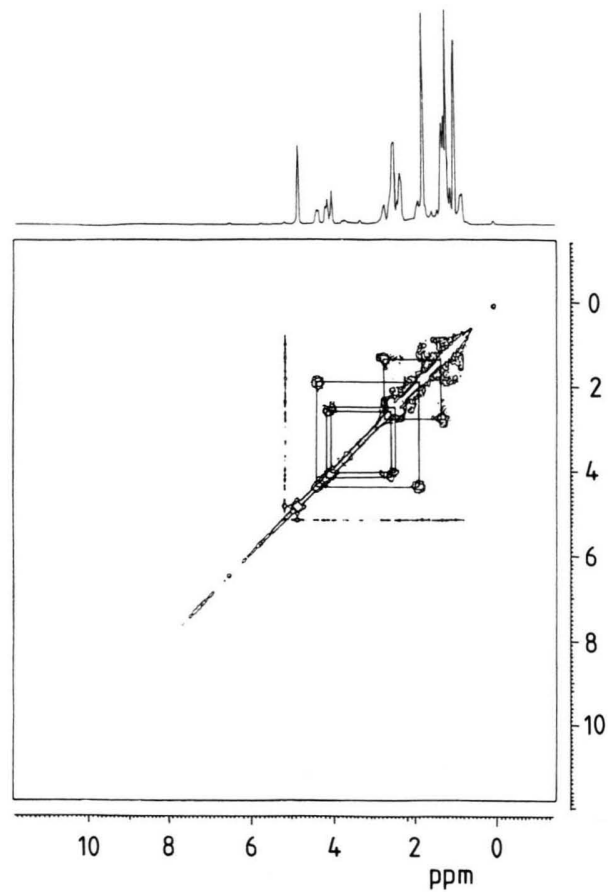

Fig. 1. Cosy-45 spectrum of pinnatifidone.
The molecular formula, obtained from mass spectrum, as well as the signals in ${ }^{13} \mathrm{C}$ NMR and ${ }^{1} \mathrm{H}$ NMR spectra indicated that the compound $\mathbf{1}$ belongs to chamigrene class of sesquiterpene with an ether bridge between $\mathrm{C}-1$ and $\mathrm{C}-10$ as in the case of nidifocene [4]. The chemical shift of methyl present at $\mathrm{C}-3$ in ${ }^{1} \mathrm{H}$ NMR of pinnatifidone is identical to nidifocene in which the positions of chlorine atom at $\mathrm{C}-3$ and $\mathrm{Br}$ at C-4 have been placed ultimately after $\mathrm{X}$-ray crystallography [5]. The positions of ketone at C-8 and methyl at C-7 have been assigned in pinnatifidone after homodecoupling experiment in ${ }^{1} \mathrm{H}$ NMR spectrum. It showed a quartet at $\delta 2.74$ $(1 \mathrm{H}, \mathrm{q}, \mathrm{H}-7)$ which after irradiation at $\delta 1.34$ simplified into a singlet. This clearly indicated the presence of ketonic function at C-8 position and a methyl group at $\mathrm{C}-7$ position. In the reverse case the signal of $\mathrm{CH}$ attached to $\mathrm{CH}_{3}$ should give a multiplet instead of a quartet. The $\mathrm{CH}_{2}$ group adjacent to $\mathrm{C}=\mathrm{O}$ group appeared at $\delta 2.58(\mathrm{dd}, J=10.0$, $5.1 \mathrm{~Hz})$.

The 14-methyl group is apparently axial because on irradiation of the signal of this group, a $33 \%$, $13.75 \%$ and $13.5 \%$ n. O.e. effect of the signals of $\mathrm{H}-7, \mathrm{H}-12$ and $\mathrm{H}-4$ was observed. There was no n. O.e. effect on $\mathrm{H}-2$ which would have been observed if 14-methyl group had been equatorial.

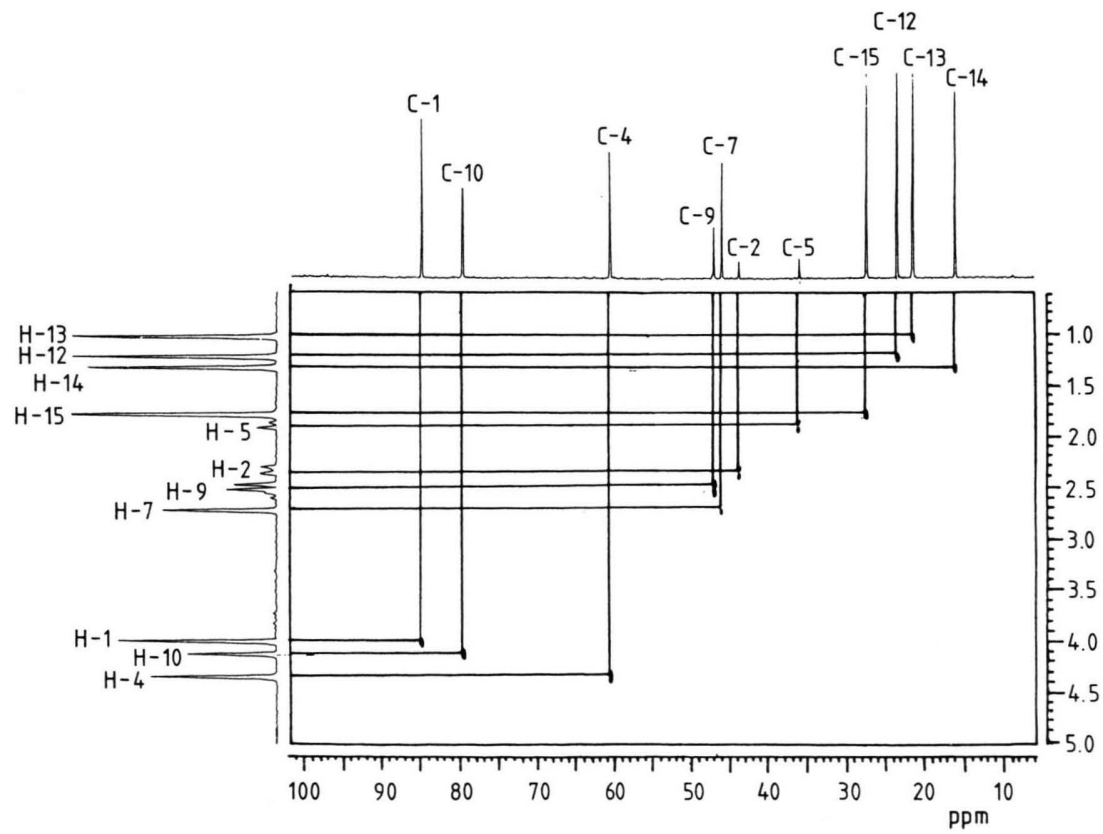

Fig. 2. Heterocosy spectrum of pinnatifidone. 


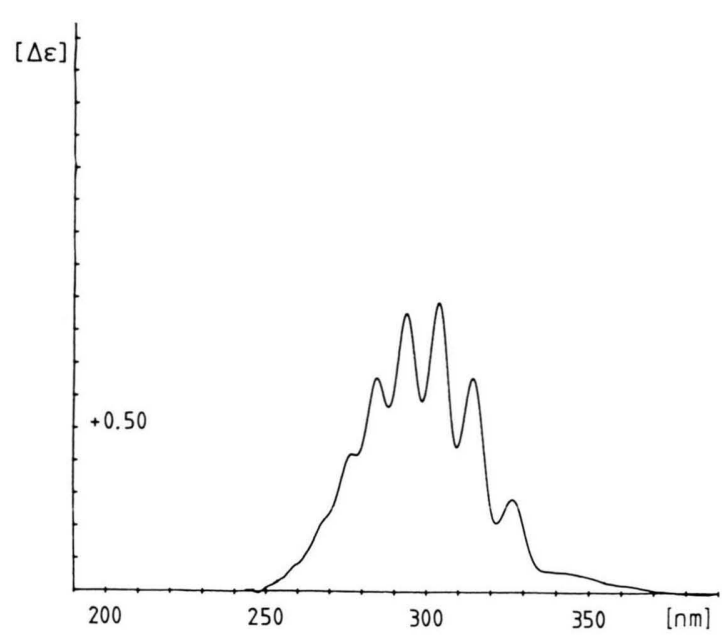

Fig. 3. CD spectrum of pinnatifidone.

The absolute configuration of $\mathbf{1}$ has been elucidated from the CD spectrum (see Fig. 3). The magnitude of the cotton effect clearly rules out a twist conformation of the cyclohexanone ring. From the molecular models it can be seen that according to the octant rule, the circular dichroism within the $n-\pi^{*}$ transition of the carbonyl group will be positive regardless of the details of cyclohexanone conformation if the absolute configuration is that as given in structure 1.

So in view of the above mentioned spectral data the structure of pinnatifidone has been assigned as $\mathbf{1}$.

\section{Experimental}

The ${ }^{1} \mathrm{H}$ NMR and ${ }^{13} \mathrm{C}$ NMR spectra were recorded in $\mathrm{CD}_{3} \mathrm{OD}$ at $300 \mathrm{MHz}$ and $75.43 \mathrm{MHz}$ respectively on Bruker AM-300.

\section{Extraction and isolation}

$3 \mathrm{Kg}$ (wet. weight) of Laurencia pinnatifida (Lamour) (herbarium No. MS-1734) was collected from the coast of Karachi and extracted in Soxhlet apparatus with chloroform and then with methanol. The methanolic extract was evaporated under reduced pressure. The residue thus obtained was partitioned between ethyl acetate and water. The ethyl acetate fraction after evaporation under reduced pressure afforded $28.3 \mathrm{~g}$ of crude extract which was subjected to silica gel column chromatography. The elution was carried out using solvent system hexane, hexane: benzene, benzene, benzene:ethyl acetate, ethyl acetate: methanol, and finally pure methanol.

The fraction eluted with pure benzene was again loaded on silica gel column which afforded $12 \mathrm{mg}$, semicrystalline compound $\mathbf{1}$. It showed no activity against gram-positive bacteria.

$[\alpha]_{\mathrm{D}}: 36.03(\mathrm{C}=0.333, \mathrm{MeOH})$.

IR $\left(\mathrm{CHCl}_{3}\right): 1700 \mathrm{~cm}^{-1}(\mathrm{C}=\mathrm{O})$.

Mass (FD): $\mathbf{M}^{+}$at $m / z 348,350,352\left(\mathrm{C}_{15} \mathrm{H}_{22} \mathrm{O}_{2} \mathrm{ClBr}\right)$.

${ }^{1} \mathrm{H}$ NMR and ${ }^{13} \mathrm{C}$ NMR: See Table I and Discussion.

We thank to International Foundation for Science (Sweden) for part of financial support. Our thanks are also due to Professor G. Snatzke, Abteilung für Chemie, Ruhr-Universität, Bochum, West Germany, for scanning the $C D$ spectrum of pinnatifidone and for helpful discussions.

Table I. ${ }^{1} \mathrm{H}$ and ${ }^{13} \mathrm{C}$ NMR Data of pinnatifidone.

\begin{tabular}{lcll}
\hline Carbon & $\begin{array}{l}{ }^{13} \mathrm{C} \mathrm{NMR}\left(\mathrm{CD}_{3} \mathrm{OD}, 75.43 \mathrm{MHz}\right) \\
(\mathrm{ppm})\end{array}$ & Proton & \begin{tabular}{l}
${ }^{1} \mathrm{H} \mathrm{NMR}\left(\mathrm{CD}_{3} \mathrm{OD}, 300 \mathrm{MHz}\right)$ \\
\hline 1
\end{tabular} \\
\hline 24.72 & 1 & $4.01(1 \mathrm{H}, \mathrm{t}, J=3.4 \mathrm{~Hz})$ \\
2 & 43.64 & 2 & $2.50(2 \mathrm{H}, \mathrm{dd}, J=11.2,2.76 \mathrm{~Hz})$ \\
3 & 70.95 & 3 & - \\
4 & 60.40 & 4 & $4.38(1 \mathrm{H}, \mathrm{dd}, J=13.8,7.0 \mathrm{~Hz})$ \\
5 & 35.83 & 5 & $1.90(2 \mathrm{H}, \mathrm{dd}, J=15.0,14.9 \mathrm{~Hz})$ \\
6 & 44.00 & 6 & $2.74(1 \mathrm{H}, \mathrm{q})$ \\
7 & 45.8 & 7 & - \\
8 & 212.46 & 8 & $2.58(2 \mathrm{H}, \mathrm{dd}, J=10.0,5.1 \mathrm{~Hz})$ \\
9 & 46.90 & 9 & $4.14(1 \mathrm{H}, \mathrm{dd}, J=12.8,6.0 \mathrm{~Hz})$ \\
10 & 79.50 & 10 & $1.23(3 \mathrm{H}, \mathrm{s})$ \\
11 & 49.93 & 11 & $1.04(3 \mathrm{H}, \mathrm{s})$ \\
12 & 23.3 & 12 & $1.34(3 \mathrm{H}, \mathrm{d}, J=7.4 \mathrm{~Hz})$ \\
13 & 21.26 & 13 & $1.80(3 \mathrm{H}, \mathrm{s})$ \\
14 & 15.85 & 14 & \\
15 & 27.31 & 15 & \\
\hline
\end{tabular}


[1] K. Usmanghani, M. Shameel, M. Sualeh, K. H. Khan, and Z. A. Mahmood, Fitoterapia, LV 2, 73 (1984).

[2] S. Bano, M. S. Ali, and V. U. Ahmad, Sci. Pharm. (Vienna) 56, 125 (1988).

[3] D. J. Martin and J. Darias, in P. J. Scheuer (ed.):
Marine Natural Products, Vol. 1, pp. 125-173, Academic Press, New York (1978).

[4] S. M. Waraszkiewicz and K. L. Erickson, Tetrahedron Lett. 18, 1443 (1976).

[5] S. M. Waraszkiewicz, K. L. Erickson, J. Finer, and J. Clardy, Tetrahedron Lett. 27, 2311 (1977). 